\title{
EDUCATION FOR SOCIAL COHESION ATTEMPTS IN LEBANON: REFLECTIONS ON THE 1994 AND 2010 EDUCATION REFORMS
}

\section{Maha Shuayb}

Centre for Lebanese Studies

Email: maha.shuayb@lebanesestudies.com

\section{ABSTRACT}

Following the end of the Lebanese civil war, education was put forward as a major means for rebuilding Lebanon and promoting social cohesion and unity. A huge education development plan was launched in 1994 culminating in a new national curriculum in 1997 and the production of new textbooks. Although the quality of education improved in public schools, dropout rates continued to be high, particularly amongst the most disadvantaged groups. As education inequality soared, a new education reform strategy was launched in 2010. This paper investigates how social cohesion has been tackled in the two reforms (1994 and 2010). In defining social cohesion, the study adopts Nancy Fraser's framework of social justice which includes redistribution, recognition, and participation. In addition, Novelli, Lopes Cardozo and Smith's (2014) fourth component of social justice 'reconciliation' is added to the analytical framework. Findings revealed an emphasis on distributive justice by widening access to education including during early years and tackling causes of dropout, specifically in the 2010 reform. Reconciliation, in particular nationalism and promoting one narrative of the past, is given a major priority. Conflict is reduced to religious intolerance while structured barriers to social justice, including the use of languages that are considered foreign as mediums of instruction, the marginalisation of disadvantaged groups, a lack of participation, and sectarian nepotism, were downplayed. Critical reflections on the past have been suppressed in favour of building a national memory.

Keywords: Lebanon; education reform; social cohesion; peace building

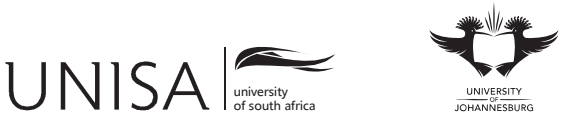

Education as Change 


\section{INTRODUCTION}

Education is a key national priority in Lebanon, where fragile conditions of social cohesion and regional strife threaten gains in social development. The national vision underpinning educational development emphasises the right to education, including accessibility and equality in opportunities and requirements of education for all, as upheld in a number of international conventions to which Lebanon is party, including the Convention on the Rights of the Child (CRC). Despite considerable efforts to address disparities in access to education, major differences persist in education quality and in student persistence and attainment, with the lowest overall indicators geographically clustered in the economically disadvantaged regions of Bekaa, South and North Lebanon, but there are also additional disparities based in particular on gender (favouring girls), age (significant drop-outs in the higher grades), disability, and refugee status (with existing challenges in educational provision to the established Palestinian refugees in the country compounded by the recent influx of Syrian refugees fleeing civil war since 2011).

Equity and equality in education are intrinsic aspects and conditions of human rights, social justice and social cohesion. Higher levels of education are associated with almost every positive life outcome, including better employment and income, health, and political and civic participation. Research has revealed a relationship between grievance and exclusion in general and in education in particular (due to discrimination on various levels in terms of resources, language, curriculum, textbooks, and policies) often resulting in state fragility and civil conflict (Berdal \& Malone 2000; Vallings $\&$ Moreno-Torres 2005). Analysis of cross-national data on education outcomes and income inequality has shown that better educated people are more likely to be involved in the political process because they have the required skills and have better access to social networks through their better jobs (Green \& Preston 2001). As a result there has been an increasing emphasis on equality and equity of education as a means to address larger social and economic inequalities and to promote social justice.

Following the end of 15 years of civil war in 1989, Lebanon launched a big initiative aimed at reforming education in order to promote social cohesion. The Taif Agreement (1989) which put an end to the civil war described education as a major means for peace building. Since then, two education reforms have taken place in Lebanon, in 1994 and 2010. This study is interested in analysing how social cohesion has been tackled and addressed in these two reforms. In doing so, the paper will first provide an overview of the Lebanese educational system followed with a discussion and a definition of the social cohesion framework it adopts in analysing the two reforms. An overview of the two reforms is offered followed by a discussion of social cohesion. 


\section{BACKGROUND ON THE LEBANESE EDUCATIONAL SYSTEM}

The Lebanese educational system is marked by a division between state-sponsored institutions and private confessional and secular schools. Prior to independence in 1943, the majority of schools were established by missionaries. Following independence, the state invested intensively in education (Farha 2012). However, in the period during and after the civil war (1975-1990), state investment in public education dropped, ceding greater place to the private sector.

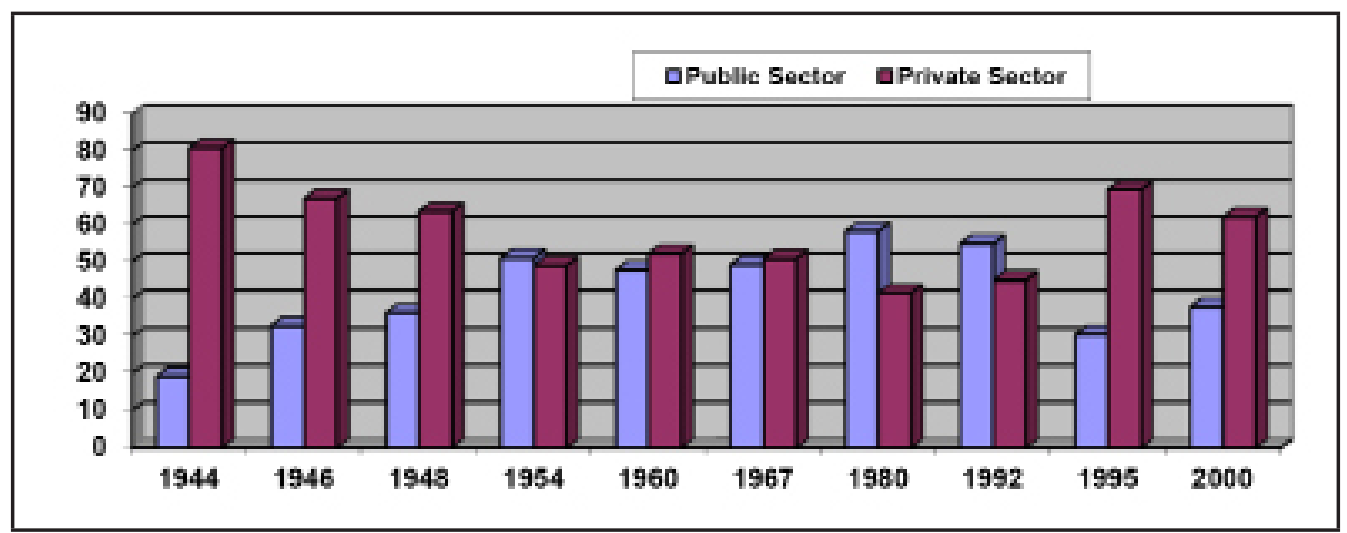

Figure 1: The evolution of public and private schools 1944 $\square 2000$

Source: Ministry of Education and CERD statistics (cited in Farha 2012).

After doubling in number by 1947, public schools surpassed the number of private schools in 1954 (51\% public schools compared to 49\% private) (Farha 2012). The state also developed its first national curriculum and invested heavily in teacher training. The education budget increased and reached its maximum in 1977 at 22 per cent of GDP.

Several factors contributed to increasing investment in education during this period. The growing civil departments of the newly established state heightened demand for educated employees as did the transformation of Lebanon from an agricultural to a service-oriented economy (based particularly on banking and tourism), which required a highly trained workforce. Education was seen to hold the key to a stable employment and social and economic prosperity and was increasingly valued by the working classes. These emerging economic and social conditions both increased the demand for schools and to a great extent shaped the educational priorities of this period.

Currently although public and private schools are almost equal in number (1365 public and 1442 private and free private), the public sector accounts for only 43.8 per cent of the 88,413 teachers employed in 2009-2010 and for only 29.2 per cent of students enrolled in the Lebanese education system in 2011 (CERD 2011). The percentage of 
students enrolled in public schools in Lebanon continues to drop due to the perception of poorer quality of teaching offered in public schools as opposed to private schools (UNDP 2009).

The non-free private sector ${ }^{1}$ on the other hand, holds more than 54 per cent of students from pre-school to secondary level and this despite the fact that there is an almost similar number of public and private schools in Lebanon, as previously noted. The remaining students are divided between free private schools (13.4\%) and UNRWA schools (3.4\%) (CERD 2011). The share of students enrolled in public schools rises as one advances along the cycle: from 26 per cent of the total at primary level, to 34 per cent at intermediate and 45 per cent at secondary level. At primary level, nearly half $(47 \%)$ of students are enrolled in fee-paying private schools and another fifth $(22 \%)$ in subsidised private schools, denoting strong parental preference for private education. This continues in primary and secondary school, where even in the absence of subsidised private schools at these levels, 61 per cent of students of intermediate level are enrolled in private schools, as are 52 per cent of secondary school students. The drop in the share of enrolment in private schools over these two levels may be related to the fact that the tuition of non-free private schools increases with the level of education, thus the increased reliance of more households on public schools at the secondary level.

The share of females of total enrolled students in public and private schools at all levels in 2011-2012 is 50.2 per cent - an increase from the 1970s when the share of enrolled females was 46.7 per cent (CERD 2011, 9). Girls are, moreover, the majority in secondary level. This could be attributed to several factors, some of which could pertain to the fact that boys are likely to drop out to enter the labour market to earn more income for their families or to the fact that many boys are now choosing to enter VTE - evidenced by a ratio of 60 per cent males in non-university VTE establishment programmes - to learn a skill which could be of use to them in finding a job (CERD 2011).

An important element that requires covering in any introduction to education in Lebanon is refugee children. Lebanon is the country with the highest per capita concentration of refugees worldwide as a result of the Syrian conflict. However prior to that Lebanon was hosting around 400000 Palestinian refugees; that is 11 per cent of the population who fled following the first Arab-Israeli war and the establishment of the state of Israel in 1948. Roughly half of them live in 12 officially designated refugee camps across the country, whilst the rest live in 27 communities known as 'gatherings' (UNRWA 2012a). The United Nations Relief and Works Agency for Palestine Refugees

1 The private education sector in Lebanon includes subsidised private schools and fee-paying ones. The former are often owned by religious charities in Lebanon where MEHE pays students' fees. These schools often include early years to Grade 6 . Free private schools on the other hand cover all grades and the tuition fees vary amongst each school. In this paper we refer to free private schools, and non-free private schools while in other cases we mention private schools. The latter when mentioned means both private free and non-free schools. 
in the Near East (UNRWA) is the designated UN body responsible for providing relief and aid as well as education to the Palestinian refugees. However, based on an agreement between UNRWA, UNESCO and the host countries in 1954, students in UNRWA schools have to be taught according to the curriculum of the hosting country. This is in order to facilitate refugees' access to the host country's secondary schools and university education (UNRWA 2012b). In the Lebanese situation, with restrictions placed on working opportunities for Palestinian refugees, certain contradictions arise. Law No 686 of 1998 restricts free and compulsory primary education to students of Lebanese nationality. This is also emphasised in the revised internal regulations for elementary schools which stipulate that only Lebanese students are eligible to register in public schools. Nevertheless, Lebanese schools do admit non-Lebanese students. According to CERD statistics for the academic year 2009-2010, while Lebanese make up 93 per cent of enrolments in public schools at all levels (2009/10), 4,581 Palestinian students were also enrolled (around $1.6 \%$ of the total), along with other nationalities - in particular 13,089 Syrians (around $4.6 \%$ of the total).

\section{A FRAMEWORK FOR SOCIAL COHESION}

Social cohesion is a concept that many countries and communities aspire to achieve. The conventional wisdom is that cohesive societies are healthy societies. Thus, the concept has become a catchphrase that often finds its way into policy documents and policy papers. Sociologists, too, have become increasingly interested in defining and understanding the factors that can promote social cohesion. A number of definitions of social cohesion is put forward in the literature - it is interpreted as a process of building shared values and reducing disparities, as a state of affairs in which people have aptitude for group collaboration, as a dialectical relationship between instituted social inclusion and exclusion mechanisms, or as the capacity of a society to ensure the well-being of all its members (Council of Europe 2004; 2005).

Social cohesion is conceptualised across academic and policy communities as a macro-goal to be fostered in order to reduce the effects of poverty, exclusion, social distrust and marginalisation. Jenson (1998) elaborates a classification using five dimensions: 1) affiliation/isolation (a sharing of common values, a feeling of belonging to the same community); 2) insertion/exclusion (a shared market capacity, particularly regarding the labour market; in other words, who has/does not have opportunities to participate in the economy); 3) participation/passivity (involvement in the management of public affairs, third sector); 4) acceptance/rejection (pluralism in facts and also as a virtue, i.e. tolerance regarding differences); and 5) legitimacy/illegitimacy (the maintenance of public and private institutions which act as mediators).

The Council of Europe (2004) defines social cohesion as a society's capacity to ensure the wellbeing of all its members by minimising disparities and avoiding marginalisation, to manage differences and divisions and to ensure the means of 
achieving welfare for all. Social cohesion is a dynamic process and is essential for achieving social justice, democratic security and sustainable development. Divided and unequal societies are not only unjust, they also cannot guarantee stability in the long term. In a cohesive society, the well-being of all is a shared goal that includes the aim of ensuring adequate resources are available to combat inequalities and exclusion.

Colletta and Cullen's definition of social cohesion is particularly useful in conflictprone societies where they define socially cohesive societies as having the following two qualities: 1) the absence of latent conflict whether in the form of income/wealth inequality, racial/ethnic tensions, disparities in political participation or other forms of polarisation; and 2) the presence of strong social bonds measured by levels of trust and norms of reciprocity, the abundance of civic society associations and the presence of institutions of conflict management (i.e. a responsive democracy, an independent judiciary, an independent media) (2000).

From a myriad of definitions two key dimensions of social cohesion emerge: 'equality', which represents the existence of equal opportunities, the absence of disparities and social inclusion; and 'social capital', which signifies the presence of strong social relations, interactions and ties within and between groups (Berger-Schmitt 2000). These two dimensions are of particular relevance in post-conflict settings where key drivers of conflict have often been inequality, discrimination, loss of trust in institutions, and the disintegration of social bonds. Hence, if we want to build a framework for studying social cohesion two factors need to be addressed, one related to reducing causes of inequalities and disparities to a minimum level to prevent feelings of marginalisation and injustice which often result in conflict and tension. Equality and justice are two core concepts in the literature on social cohesion.

Fraser (2005) defines justice as "“parity of participation" and emphasises that overcoming injustice means dismantling institutionalised obstacles that prevent some people from participating on a par with others, as full partners in social interaction' (2005, 73). Fraser highlights three important components to tackle injustice: the economic, the cultural and the political. Addressing these three elements requires an emphasis on redistribution, recognition, and participation respectively. Fraser (2008) stresses the need to address these factors on a structural level. She characterised two types of remedies to social injustice: 'affirmative remedies', which correct outcomes without changing structural frameworks or the status quo, and 'transformative remedies', which correct outcomes by restructuring the underlying generative framework (Fraser 1995).

Novelli, Lopes Cardozo and Smith (2014) argue that the key post-conflict transformations necessary to produce sustainable peace involve redistribution, recognition and representation, to bring about greater social justice as suggested by the work of Fraser (2005). However they add a fourth dimension which is reconciliation, a necessary dimension in conflict areas. These components must be addressed in any proposals that aim to promote justice and cohesion. Novelli and Smith (2012) criticised what Paris (2004) called 'the liberal theory of peace education' which focuses on 
security at the expense of social sector spending. This thesis of peace prioritises security and the rule of law, democratic elections and the promotion of a free-market economy. Instead of the liberal theory of peace, Novelli, Lopes Cardozo and Smith (2014) suggest a '4Rs framework' for justice as the basis for any work on peace or social cohesion. Accordingly, social cohesion needs to address structural obstacles that undermine access to resources, recognition, representation and reconciliation. Novelli, Lopes Cardozo and Smith's thesis claims that a sustainable approach to peacebuilding places more emphasis on social development and addresses underlying causes of conflict such as political, economic and social inequalities and injustices. In this they stress Fraser's theory of justice. They also argue that education has a major role to play in this through 'transformational' strategies that are defined in terms of the extent to which education policies, individual and institutional agency, and development programmes promote redistribution, recognition, representation and reconciliation $(2014,2)$. Consequently Novelli, Lopes Cardozo and Smith (2014) developed an analytical framework for examining education in conflict-prone societies using the 4Rs summarised below:

Table 1: The 4Rs framework

\begin{tabular}{|c|c|}
\hline $\begin{array}{l}\text { Redistribution } \\
\text { (Addressing } \\
\text { Inequalities) }\end{array}$ & $\begin{array}{l}\text { - Quantitative analysis of existing data to examine vertical and horizontal } \\
\text { inequalities relevant to education inputs, resources and outcomes. } \\
\text { - Analysis of macro education reforms or policies to see if they are } \\
\text { redistributive, for example, the impact of decentralisation, privatisation, } \\
\text { how they impact different groups and affect conflict dynamics. }\end{array}$ \\
\hline $\begin{array}{l}\text { Recognition } \\
\text { (Respecting } \\
\text { Difference) }\end{array}$ & $\begin{array}{l}\text { - Language of instruction policies. } \\
\text { - Recognition of cultural diversity through curriculum. } \\
\text { - Place of religious identity in the education system. } \\
\text { - Citizenship and civic education as a means of statebuilding. }\end{array}$ \\
\hline $\begin{array}{l}\text { Representation } \\
\text { (Encouraging } \\
\text { Participation) }\end{array}$ & $\begin{array}{l}\text { - Extent to which education policy and reforms are produced through } \\
\text { participation (local, national, global). } \\
\text { - Analysis of political control and representation through the administration } \\
\text { of education. } \\
\text { - School governance, school based management, involvement in decision } \\
\text { making (teachers, parents, students). } \\
\text { - Extent to which education system supports fundamental freedoms. }\end{array}$ \\
\hline $\begin{array}{l}\text { Reconciliation } \\
\text { (Dealing with } \\
\text { Past, Present } \\
\text { and Future } \\
\text { Injustices) }\end{array}$ & $\begin{array}{l}\text { - Addressing historical and contemporary economic, political and cultural } \\
\text { injustices that underpin conflict. } \\
\text { - Analysis of how education contributes to integration and segregation } \\
\text { (social cohesion, common institutions). } \\
\text { - Teaching about the past and its relevance to the present and future. } \\
\text { - Levels of trust - vertical (trust in schools and the education system) and } \\
\text { horizontal (trust between different identity-based groups). }\end{array}$ \\
\hline
\end{tabular}

This study will use this framework in analysing social cohesion in the 1994 and 2010 education reforms. Before doing so, we provide an overview of these two reforms. 


\section{THE 1994 EDUCATION REFORM}

The Taif Accord, which put an end to the civil war in 1989, initiated a major educational reform. It called for the development of a new curriculum which promotes national unity. Section 3.F.5 of the Taif agreement states that 'the curricula shall be reviewed and developed in a manner that strengthens national belonging, fusion, spiritual and cultural openness' (Government of Lebanon 1989). As a result, the plan for reforming education and rebuilding the public education sector started. In the following section we examine the 1997 reform and analyse its approach to social cohesion.

In 1994, the government set out its 'Educational Recovery Plan' for the reform of the educational system, which had remained unchanged since 1959. The main objectives of the new plan were to raise the standards of education, enhance the infrastructure needed for the provision of free education to all Lebanese children, and review the transition between academic and technical education. The plan also stipulated the development of a new school curriculum.

The Educational Recovery Plan took into account international agreements on the protection of children, such as the Convention on the Rights of the Child (CRC) ratified by the GOL in 1991, without reservations. As a result, Decree 134/59 of the year 1959 was amended in 1998 from 'Free elementary education for all Lebanese children' to 'Compulsory free elementary education for all Lebanese children', though the government has not yet issued the legal steps necessary to enforce compulsory free education across the country (ILO 2004, 38).

In 1995, the Council of Ministers approved the 'New Framework of Education in Lebanon' and a new curriculum and textbooks were introduced in 1997. The framework has been described as 'a tectonic shifting from the political objectives accented by the Education Development Plan to the recognition of the structure, content and styles of pedagogy of Lebanon's curriculum' (Abouchedid et al. 2002, 4).

The framework and its new curriculum were developed by the Centre for Educational Research and Development (CERD) which is made up of educational experts, teachers from different sectarian groups, government bodies and religious advisors. Abou Assali (2012), the Director of CERD during that period who oversaw the development of the new curriculum and its implementation, summarises MEHE's approach to social cohesion in the following figure. 


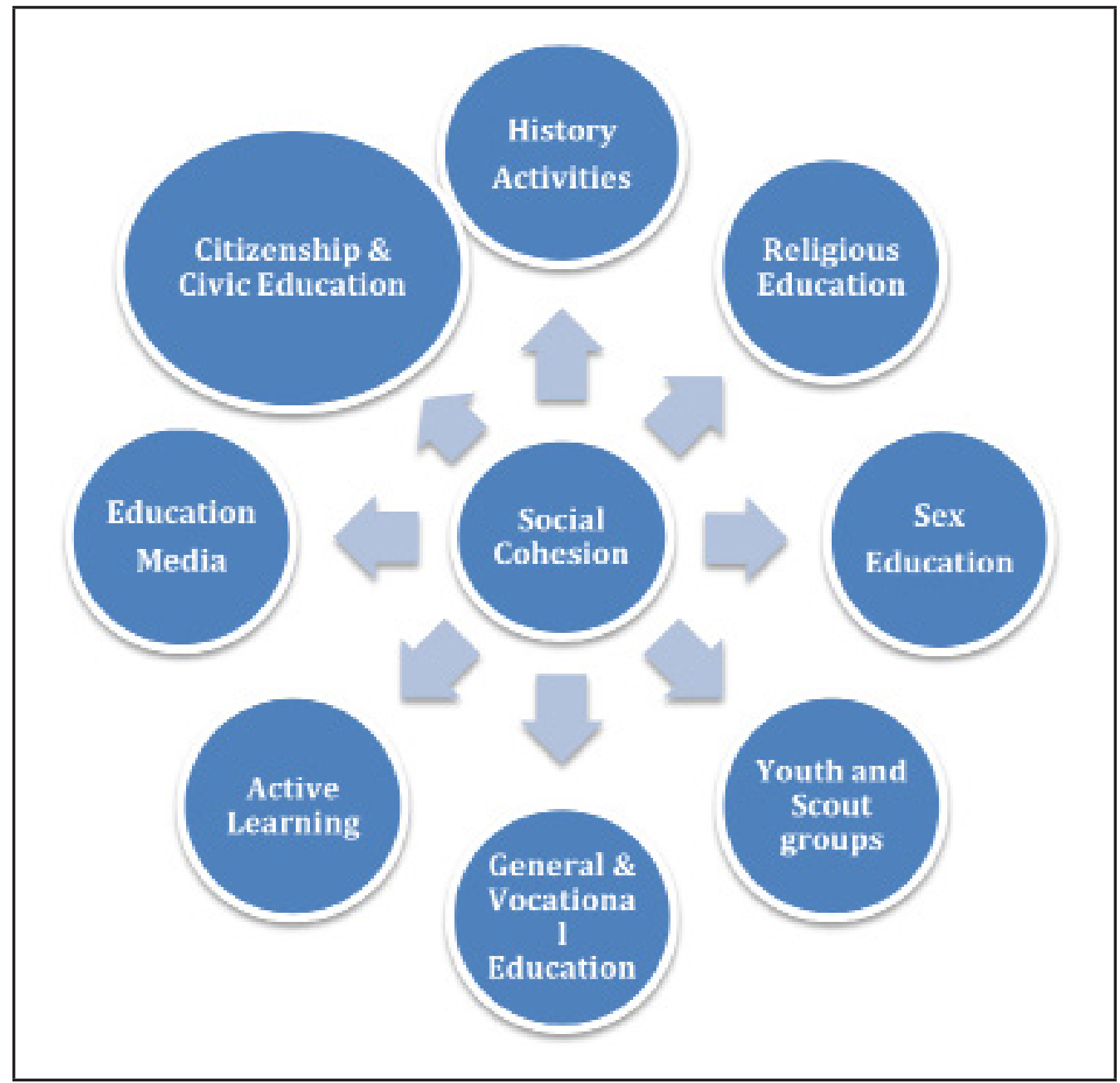

Figure 2: The approach to social cohesion in the 1994 education reform plan

MEHE's approach to social cohesion post-civil war addresses some of the components of the $4 \mathrm{R}$ model. We see a big emphasis on reconciliation through Civic education, History and Religious studies. Redistribution and recognition are not highlighted while participation is addressed under active learning and scouts groups. An overview of the principles underpinning the 1997 curriculum shows the big emphasis placed on nation building, unity and the Lebanese identity as means for building peace and social cohesion.

Social justice, equity and non-discrimination on religious or ethnic bases and openness to other cultures are each mentioned only once in the principles. Achieving reconciliation is attempted through promoting shared values and a strong sense of 
national pride. Poor nationalism and loyalty to the country are seen as the main underlying threats to social cohesion rather than issues of social justice and equality. This is in line with the sectarian analysis of the causes of the Lebanese civil war that attributes the war to the lack of consensus amongst Lebanese confessional groups concerning their nationalist identity, primarily between the Muslims, who saw their identity as being closer to the Arabs, and Christians, who tried to distance themselves from the Arab identity. However, other analyses of the causes of the civil war see sectarianism merely as the face of a political and socio-economic struggle that was deployed to take a sectarian form (Traboulsi 2007; Hanf 2015). As noted by Hanf $(2015,110)$, 'the social conflict of the 1960s and early 1970s was between strata, classes, and interest groups, not communities'. The Taif appears to adopt the first analysis of the causes of the civil war, manifested in the limited importance given to the class struggle while overemphasising the role of the sectarian cleavages. As a result, the 1994 education reform exacerbates the importance of shared identity and reconciliation. Unifying Citizenship, Religion and History textbooks and developing a shared identity and memory are seen as two main means for nation building. Yet, the four different attempts to develop a History curriculum and textbooks have failed, while Religious education became optional for school principals to decide whether to teach it or not.

To sum up, the 1994 education strategy priorities the unification of textbooks and developing a shared memory as major means for promoting social cohesion. Two decades later, questions concerning the effectiveness of the 1994 strategy to promote social cohesion have come to the fore as inequalities in access to education continued to increase. To date, the public sector attracts less than 20 per cent of the student population in the primary stage. The gap between the public and private schools widened. Public schools became the resort of the most disadvantaged groups in Lebanon who cannot even afford the low budget private schools. School dropouts also increased, as we shall show later, amongst the most disadvantaged groups. The need for a new reform became more pressing. Finally, and after three different incomplete reform attempts, a new educational strategy saw the light in 2010.

\section{THE 2010 EDUCATION REFORM}

In 2005, a National Action Plan for Education for All was adopted in Lebanon, aimed at offering all children in society a good quality education, with a particular emphasis on girls and disadvantaged children. The National Action Plan aspired to achieve a 50 per cent increase in adult literacy rates by 2015, particularly among women (Government of Lebanon 2006). Thereafter, in 2007, MEHE prepared a National Educational Strategy in Lebanon (NES) (MEHE 2007), which encompasses many of the key components of a human rights and equity-based education. The following table summarises the main objectives of this strategy. 
Table 2: $\quad$ Priorities for education sector development (2010-2015)

\begin{tabular}{|l|l|l|l|}
\hline \multicolumn{2}{|l|}{ NES (2007) } & \multicolumn{2}{l|}{ ESDP (2010-2015) } \\
\hline 1. & Education available & 1. & Early childhood education \\
\cline { 3 - 4 } & on the basis of equal & 2. & Improving retention and achievement \\
\cline { 3 - 4 } & opportunity & 3. & Development of infrastructure \\
\hline 2. & $\begin{array}{l}\text { Quality education that } \\
\text { contributes to building a } \\
\text { knowledge society }\end{array}$ & 4. & Professionalisation of the teaching workforce \\
\cline { 3 - 4 } & 5. & Modernisation of school management \\
\cline { 3 - 4 } 3. & $\begin{array}{l}\text { Education that } \\
\text { contributes to social } \\
\text { integration }\end{array}$ & 7. & Achievement assessment and curriculum development \\
\hline 4. & $\begin{array}{l}\text { Education that } \\
\text { contributes to economic } \\
\text { development }\end{array}$ & 8. & Citizenship education \\
\cline { 3 - 4 } & $\begin{array}{l}\text { Governance of } \\
\text { education }\end{array}$ & 10. & Intion Education \\
\hline
\end{tabular}

The above table presents the ten main priorities adopted by national Education Sector Development Plan (ESDP) which was approved by the Council of Ministers in 2010. The new education reform emphasises many of the issues essential for the achievement of equality in access and quality in education. The vision document which underpins the strategy (MEHE 2007) addresses many of the current gaps including: provision for education in the early years, attention to drop-out rates, inclusion of vocational education and consideration for students with special needs. It highlights the gap in success rates in official exams between the public and private sectors and emphasises the importance of counselling and guidance. At the same time, the scope of the document is limited to students of Lebanese nationality. No provisions are made for refugee students, who are seen to fall outside of the Lebanese system. The document does not refer to the needs or the challenges that non-Lebanese students might encounter. Nor does the vision address any additional support required for Lebanese students who come from disadvantaged backgrounds who are at high risk of underperforming and dropping out of school. The plan does not address the issue of learning a foreign language which is considered as one of the main objectives of the Lebanese curriculum yet is also considered as a main factor leading to the dropout of students.

\section{DISCUSSION}

If we apply the 4Rs framework in analysing the 1994 and 2010 strategies we see that both emphasised the distributive dimension of social cohesion manifested in the emphasis on the right to education for all. In 2010, access to education has been extended to include early years. The 1994 reform plan restructured the educational system by giving more 
choice to students in the secondary phase as well as providing vocational students with the opportunity to join mainstream higher education. This would certainly help tackle issues of inequalities. The plan also placed big emphasis on restoring the image of public schools and rebuilding many of the schools destroyed during the war. The reform did not touch in any way on private schools or challenge their prerogatives; on the contrary it sought the expertise which the private sector gained during the years of war to rebuild the public education system. This was seen as a means for promoting cohesion. The 1994 reform had hoped that by strengthening the public education system, it would become a more popular choice for parents. While this did actually happen for a few years following the 1994 reform, the improvement, manifested in the increasing number of students in public schools between 1997 and 2004, has started to deteriorate since then. To date, private schools continue to absorb the majority of Lebanese students for several reasons, including the poor quality of education in public schools, the state financial allowances given to public servants to enrol their children in private schools, the ownership of private schools by several politicians etc. Finally, and to conclude the distributive aspect of social justice, both reforms, 1994 and 2010, did not discuss in particular how they will address the educational gaps between regions, especially given that historically Lebanese peripheries have suffered from under development, which some people argue is one of the factors that contributed to the breakout of the war (Traboulsi 2007). They also discounted the education of refugee children (despite receiving waves of refugee children from Iraq) and how the reforms will exacerbate their already modest education attainment. Historically, UNRWA is the official authority appointed the responsibility of overseeing the education of Palestinian refugees in Lebanon and there is a rupture between MEHE and UNRWA.

While the two reforms underplayed equality as an issue undermining social justice and cohesion, they did however focus on nation building and nationalism. In particular, the 1994 reform, which came after the civil war, focused on reconciliation throughout its various components, especially in the curriculum aims and objectives as well as throughout the textbooks. This brings us to the second component of social justice: recognition.

In Novelli, Lopes Cardozo and Smith's (2014) framework on social justice recognition encompasses language of instruction policies, and the recognition of cultural diversity through curriculum and civic education as means for state building. If we start with the last two, there is ample weight given to citizenship and recognition of diversity of religions in both reforms but particularly in the 1994 reform as it was formulated straight after the civil war. Nonetheless, teaching the 1997 unified Citizenship textbooks for over 25 years did not put an end to the clashes between the Lebanese nor did it bring about a peaceful Lebanon. Research on Citizenship education in Lebanon revealed a number of shortcomings. The heavily nationalistic flare adopted in the 1997 Citizenship textbooks seemed to be more concerned with civic literacy than civic participation (Shuayb 2012). Content analysis of these textbooks revealed major gender biases, and social stereotyping (Shuayb 2015; Zoreik 2000). In the classroom, researchers showed 
that most practices emphasised rote learning (Abouchedid et al. 2002; Akar 2007; Shuayb 2007; 2012; UNDP 2009). In many cases, teachers avoided dialogic pedagogies in fear of conflicts among students and with parents (Akar 2007; Zakharia 2012). Moreover, students and teachers described the textbook as inaccurate, repetitive and conflicting with reality, resulting in students' low levels of motivation to learn civics (Akar 2006). Studies on identity and sense of belonging in Lebanon showed that the majority of students did not know much about sects other than their own, and felt their primary sense of belonging was to their family and sect rather than to their nation (Shuayb 2012; Abouchedid et al. 2002; UNDP 2008). These findings indicate a shortfall of the literacy-oriented Citizenship education and the need for an active and critical approach where controversial topics are addressed rather than avoided. Adopting a consensus approach to the development of curriculum and textbooks limits opportunities to prepare individuals to think critically and creatively about issues affecting their current lives. The single narrative, used in most public Lebanese schools, provides children with no opportunity to question and answer big questions. Instead, they learn only to remember information in order to recite for exams.

Another component of recognition is languages of instruction. Language was a much-debated issue during the 1994 reform. There were two camps: the first wanted to advocate for a multicultural and multilinguistic Lebanon, while the other emphasised the Arabic language and identity of the country. The compromise between the two camps was to produce Maths and Science textbooks in three languages (Arabic, English and French) up to Grade 6, after which textbooks are only offered in English or French. It is worth noting that according to the curriculum English and French are taught as foreign languages and not second languages. This decision resulted in high dropout rates amongst the most disadvantaged groups in Lebanon who have limited and poor exposure to French or English. The peak of the dropout seems to take place in Grade 6 and 7 when schools shift to teach Maths and Science in a foreign language. The dropout rates are manifested in the net enrolment rates for Lebanese students, which drop from 92.7 per cent in primary level to 68.5 per cent in intermediary level. Children, particularly boys in the North of Lebanon and Bekaa as well as refugees in Palestinian camps had the highest drop-out rate and lowest completion rate (Shuayb 2014). It can be argued that the language policy in Lebanon has exacerbated education inequalities in Lebanon and has doomed the education attainment of many children from disadvantaged backgrounds.

Concerning representation and participation, we notice that the process of the 1994 reform was highly inclusive of the various religious, sectarian and economic sectors in Lebanon. Teachers, principals, researchers, and academics from both the private and public sectors were involved in the reform. The two main stakeholders missing from this participatory approach were Lebanese and Palestinian students and parents. As for the 2010 reform, its development process was limited to academics belonging to a small association of educationalists. Students', teachers' and parents' consultations in the 
development of the 10 priorities were missing. To date, students in public schools are prohibited from having students' councils, or participating in demonstrations or political parties. Teachers are also denied the right to demonstrate or to form unions. In fact, in the name of reconciliation and peace, students' and teachers' voices continue to be suppressed. This brings us to the last component of Novelli, Lopes Cardozo and Smith's (2014) social justice framework, which is reconciliation.

While reconciliation was the prime objective and top priority of the 1994 reform as stated in the aims of the curriculum, it is also addressed in the 2010 strategy, which seeks to promote nationalism through Citizenship education. According to the 1994 plan, the measures taken to promote reconciliation include attempting to reunify History textbooks and building one shared memory and narrative of the past. It also sought to replace sectarian Religious education with a unified Religious education textbook. However, both attempts have failed. The heads of the various sectarian groups blocked attempts to unify Religious education. The best that could be achieved at that time was to make Religious education optional for the principals to decide whether to include it or not. If offered, a religious leader who belongs to the same sect as the majority of students in the school teaches the subject using textbooks designed by the council of the religious group. Students belonging to other sects can choose to attend the class or leave, which exacerbates divisions. The 1994 reform seems to focus mainly on religious reconciliation, and neglects elevating social and economic and structural obstacles that undermine the integration of various groups such as non-Lebanese nationals (including refugee children), disabled children and other marginalised groups. The gap between the private and public sectors remained unaddressed. This strategy seems to be followed but to a lesser extent in the 2010 strategy as it addresses issues of retention and dropout as well vocational education, both of which target disadvantaged groups.

\section{CONCLUSION}

Designing an education reform that promotes social cohesion requires 'transformative remedies' that correct outcomes by restructuring the underlying generative framework and not 'affirmative remedies' that correct outcomes without changing structural frameworks or the status quo (Fraser 1995, 82, 86). Social cohesion needs to embedded in a discourse of social justice which requires developing policies and practices tackling four levels: redistribution, recognition, representation and reconciliation. Analysing the last two education reforms post-civil war in Lebanon (1994 and 2010) using Novelli, Lopes Cardozo and Smith's (2014) framework showed big emphasis on reconciliation, in particular on nationalism and a shared memory of the past. In the reforms, conflict is reduced to religious intolerance while structured barriers including the use of what are considered foreign languages as mediums of instruction, the marginalisation of disadvantaged groups, and participation have been downplayed. While developing a national Citizenship and History curriculum could contribute to reconciliation the MEHE 
consensual approach failed to succeed in bringing about a new History curriculum and textbooks. Citizenship education has also been reduced mainly to civic literacy. Nonetheless, both reforms addressed distributive justice by seeking to widen access to education including during the early years and tackling causes of dropout, specifically in the 2010 reform.

Both reforms overlooked the participation and representation of students and various social groups who have been marginalised. They also did not tackle any of the structural barriers, namely policies that widen the gap between the two sectors such as the financial support MEHE provides to private schools through school vouchers to its civil servants to put their children in private schools or teachers' appointments etc.

As the year 2016 is almost coming to an end, the majority of the objectives of the 2010 strategy have not been achieved. MEHE is currently planning to launch a new strategy. Before doing this, there is a need to discuss the framework that needs to be adopted to promote social cohesion. Having used Novelli, Lopes Cardozo and Smith's (2014) framework for social justice in this analysis of Lebanon's education reforms, it seems the reforms' view of social cohesion is restricted to nationalism. Novelli, Lopez Cardozo and Smith's framework allows us to address the structural factors that undermine social justice and cohesion. With regards to Lebanon's education reforms, the reconciliation and recognition dimensions need to include a critical dimension as History and civic education can be used as means for pacifying students and advocating dogmatism.

\section{REFERENCES}

Assali, M.A. 2012. Education for social cohesion in Lebanon: The education reform experiment in the wake of the Lebanese civil war. In Rethinking education for social cohesion: International case studies. Edited by M. Shuayb. London: Palgrave McMillan.

Abouchedid, K, R. Nasser and J. Van Blommestein. 2002. The limitations of inter-group learning in confessional school systems: The case of Lebanon. Arab Studies Quarterly 2(4): 61-82.

Akar, B. 2006. Teachers' reflections on the challenges of teaching citizenship education in Lebanon: A qualitative pilot study. Reflecting Education 2(2): 48-63.

Akar, B. 2007. Citizenship education in Lebanon: An introduction into students' concepts and learning experiences. Educate 7(2): 2-18.

Berdal M. and T. Malone. 2000.Greed and grievance. Economic Agendas in civil wars. Boulder, CO: Lynne Rienner.

Berger-Schmitt, R. 2000. Social cohesion as an aspect of the quality of societies: Concept and measurement. EU Reporting Working Paper No. 14, Centre for Survey Research and Methodology, Manheim, Germany.

CAS. 2006. Living conditions of households 2004. Ministry of Social Affairs. Beirut. http://www. cas.gov.lb/index.php/all-publications-en\#households-living-conditions-survey-2004 (accessed 4 November 2016). 
Central Administration Statistics, UNICEF. 2009. Multiple indicator cluster survey 3 - Lebanon.

Center for Educational Research and Development. 2000. Compulsory education in Lebanon: The need for public education. Retrieved from: http://www.crdp.org/ (accessed 4 November 2016).

Center for Educational Research and Development. 2005. Statistical bulletin. Retrieved from: http:// www.crdp.org/ar/statistics-bulletin (accessed 21 November 2016).

Center for Educational Research and Development. 2011. The Non-educational factors that affect students' failure and dropout: The state of public schools in Lebanon, basic education. Beirut: CERD.

Colletta, N.J. and M.L. Cullen. 2000. Violent conflict and the transformation of social capital: Lessons from Cambodia, Rwanda, Guatemala, and Somalia. Washington, DC: World Bank.

Council of Europe. 2004. A new strategy for social cohesion. European Committee for Social Cohesion. Retrieved from: http:/www.coe.int/t/dg3/socialpolicies/socialcohesiondev/source/ RevisedStrategy_en.pdf (accessed 25 November 2016).

Council of Europe. 2005. Concerted development of social cohesion indicators: Methodological guide. Strasbourg, Council of Europe. Retrieved from: http://www.coe.int/t/dg3/socialpolicies/ socialcohesiondev/source/GUIDE_en.pdf (accessed 25 May 2011).

Farha M. 2012. The historical legacy and political implications of state and sectarian schools in Lebanon. In Rethinking education for social cohesion: International case studies. Edited by M. Shuayb. London: Palgrave McMillan.

Fraser, N. 1995. From redistribution to recognition? Dilemmas of justice in a 'post-socialist' age. New Left Review 212: 68-93.

Fraser, N. 2005. Reframing justice in a globalised world. New Left Review 36: 79-88.

Gewirtz, S. 2000. Bringing the politics back in: A critical analysis of quality discourses in education. British Journal of Educational Studies 48(4): 352-70.

Government of Lebanon. 1989. The Taif Agreement. Retrieved from: https:/www.un.int/lebanon/ sites/www.un.int/files/Lebanon/the_taif_agreement_english_version_.pdf (accessed 16 November 2016).

Government of Lebanon. 2006. Consideration of reports submitted by states parties under article 18 of the Convention on the Elimination of All Forms of Discrimination against Women: Third periodic report of states parties, Lebanon, CEDAW/C/LBN/3. Committee on the Elimination of Discrimination against Women.

Green, A. and J. Preston. 2001. Education and social cohesion: Re-centering the debate. Peabody Journal of Education and Development 76(3 \& 4): 247-284.

ILO. 2004. Gender education and child labour in Lebanon. Retrieved from: http://www.ilo.org/ ipecinfo/product/download.do?type=document\&id=341 (accessed 3 November 2016).

Jenson, J. 1998. Mapping social cohesion: The state of Canadian research. Ottawa: Canadian Policy Research Networks.

Lebanese Association for Education Studies. 2007. National education strategy in Lebanon: Vision document, Ministry of Education and Higher Education educational development project. Beirut: MEHE. Retrieved from: http://www.laes.org/upload/editor_upload/file/Vision $\% 20$ Document $\% 20 \% 20$ English.pdf (accessed 21 November 2016).

Maxwell, J. 1996. Social dimensions of economic growth. Eric John Hanson Memorial Lecture Series. Vol. 8. Edmonton: University of Alberta. 
MEHE. 2010. Quality education for growth: National education strategy framework. Education sector development plan (general education): 2010-2015. Beirut: MEHE.

MEHE. 2011. D-RASATI Field Survey Report.

Ministry of Social Affairs. 2011. The national social development strategy of Lebanon. Retrieved from: http://www.databank.com.lb/docs/National\%20Social\%20Development $\% 20$ Strategy $\% 20$ 2011.pdf (accessed 3 November 2016).

McBride, S., L.A. Dirani and S.H. Mukalid. 1999. A needs assessment of the Lebanese educational system in the field of special education. Beirut: UNESCO.

Novelli, M. and A. Smith. 2012[2011]. The role of education in peacebuilding: A synthesis report of findings from Lebanon, Nepal and Sierra Leone. UNICEF: New York.

Novelli, M., M. Lopes Cardozo and A. Smith. 2014. Consortium on education and peacebuilding, research briefing 2: Theoretical and analytical framework. Learning for Peace. Retrieved from: http://learningforpeace.unicef.org/wp-content/uploads/2014/11/PBEA-Briefing-Paper-2Nov14-FINAL.pdf (accessed 21 November 2016).

Shuayb, M. 2007. Education: A means for the cohesion of the Lebanese confessional society. In Breaking the cycle. Edited by Y. Choueiri Y, 167-195. London: Stacey International.

Shuayb, M., ed. 2012. Rethinking education for social cohesion: International case studies. London: Palgrave McMillan.

Shuayb, M. 2014. The art of inclusive exclusions: Educating the Palestinian refugee students in Lebanon. Refugee Survey Quarterly 33(2): 1-18.

Shuayb, M. 2015. Human rights and peace education in the Lebanese civics textbooks: A comparative lens. Research in Comparative and International Education March, 10(1).

Traboulsi, F. 2007. A history of modern Lebanon. London: Pluto Press.

UNESCO. Forthcoming. Children's rights, gender, conflict and violence management and dialogue in the national Lebanese Citizenship and Civics textbooks: A content analysis.

UNICEF. 2010. The situation of Palestinian children in the occupied Palestinian territories, Jordan, Syria and Lebanon. An assessment based on the Convention on the Rights of the Child. Retrieved from: https://www.unicef.org/oPt/PALESTINIAN_SITAN-final.pdf (accessed 4 November 2016).

UNDP. 2009. Lebanon 2008-2009: The national human development report - Towards a citizen's state. Beirut: UNDP.

UNRWA. 2012a. Where we work: Lebanon. Retrieved from: http://www.unrwa.org/where-we-work/ lebanon (accessed 20 November 2016).

UNRWA. 2012b. Assuring quality curriculum in UNRWA schools. Beirut: UNRWA. Retrieved from: http://www.unrwa.org/resources/strategy-policy/assuring-quality-curriculum-unrwa-schools (accessed 19 November 2016).

Vallings C. and M. Moreno-Torres. 2005. Drivers of fragility: What makes states fragile? DFID Working Paper. London: DFID.

World Bank. 2010. Lebanon implementation completion and results report. Education Development Project. Washington, DC: World Bank.

Young, I.M. 1990. Justice and the politics of difference. New Jersey: Princeton University Press. 
Zakharia, Z. 2012. Education and peacebuilding in crisis and post-conflict contexts: Lebanon country study. New York: UNICEF.

Zoreik, A. 2000. Civics education: How do we deal with it. Beirut: Arab Scientific Publishers. 